\title{
Biochemical Changes in the Serum and Liver of albino rats exposed to Petroleum Samples (gasoline, kerosene, and crude Petroleum).
}

\author{
${ }^{1}$ AYALOGU, O. E; ${ }^{1}$ IGBOH N. M; ${ }^{2}$ DEDE E. B ${ }^{*}$ \\ ${ }^{1}$ Department of Biochemistry, Faculty of Science, University of Port Harcourt, PMB 5323, Port Harcourt, Nigeria. \\ ${ }^{2}$ Department of Pharmacology, College of Health Sciences, University of Port Harcourt, PMB 5323, Port Harcourt, Nigeria.
}

\begin{abstract}
Biochemical changes in the serum and liver of albino rats chronically exposed to rats administered $5 \mathrm{gk}^{-1}$ , $7.5 \mathrm{gk}^{-1}$ and $15 \mathrm{gk}^{-1}$ of gasoline, kerosine and crude petroleum(bonny light) respectively were studied. The petroleum samples were administered intraperitoneally and the biochemical changes in the rat serum and the liver wree monitored over a three monthduration:Asparate amino transferase (AST) Alanine amino transferas (ALT) and Alkaline Phosphate (ALP) all showed dose- dependent increase in levels from zero month to $3^{\text {rd }}$ month, gasoline from $19.0 \pm 2.8$ of control to $69.0 \pm 12.8$ third month kerosine $19.0 \pm 2.8$ control to $58 \pm 5.0$ third month and crude Petroleum $19.0 \pm 2.8$ control to $33.2 \pm 1.3$ at the third month. Alanine amino transferase increase from $12.0 \pm 1.1$ of control to $62.0 \pm 6.0$ at the third month with gasoline, also from $12+1.1$ of control to $29.7+5.6$ in the third month with kerosene and from $12.0 \pm 1.1$ of control to 27. \pm 3.1 at the third month with crude petroleum. Furthermore, the alkaline phosphatase increase from 62.1 $\pm 3.0 \mu / \mathrm{l}$ control to $161.0 \pm 2.0$ at the third month for gasoline, kerosene from $62.1 \pm 3.0$ of control to $123.6 \pm 12.6 \mu / l$ at the third month, with crude petroleum (bonny light) increasing from $62.1 \pm 3.0 \mu / 1$ of control to $90.5 \pm 6.3 \mu / \mathrm{l}$ at third month. Glutathione transferase (GST) was marginally increase in gasoline treated rats from $13.0 \pm 0.8 \mu / 1$ of control to $17.0 \pm 1.0 \mathrm{u} / \mathrm{l}$ however, greater elevation in level of the enzyme was obtained in kerosene treated rats from $13.0 \pm 0.8 \mu / l$ of control to $25.2 \pm 2.0 \mu / \mathrm{l}$ at the third month. Finally the reducedglutathione (GSH) seemed to be depleted from $0.56 \pm$ $0.1 \mathrm{mM}$ of control to $0.43 \pm 0.1$ at the third month with gasoline, $0.30 \pm 0.1 \mathrm{mM}$ at the third month with kerosene and $0.41 \pm 0.1 \mathrm{mM}$ at the third month with crude petroleum (bonny light). In conclusion the petroleum sample caused biochemical changes in the serum andliver of the rats. @ JASEM
\end{abstract}

The importance of detoxification of exogenous compounds including petroleum products is under scored by the ever increasing number of environmental and other chemical substances to which the body is exposed. Detoxification is a process where by atoxic substance is inactivated subsequentto its removal from the body, is primarilly a hepatic and a renal function (Derek and Ewart, 1980). Report of Derek and Ewart 1990, indicated that endogenous ane exogenous substances undergo hepatic conjugation to facilitate its excretion.Repot of Patric and Mc Gee, 1988 also indicated that the liver has a valuable role in the detoxification of many substances:Report of et al , 1983 has shown that glutathione (GSH) a tripeptide containing Lglutamic acid, and glycine is employed in detoxification reactions. Report of Martin et al, 1983 further indicated that a large reserve of GSH is represented in the hepatocytesto meet demands of utilizationin detoxification.

Hatchcrot, (1982) had report glutathione - s - transferase as the enzyme which function as cellular protective enzyme, which catalyses the nuetralization of the chemically reactive intermidiate by coupling with glutathione resulting in the formation of usually non-reactive conjugated products. Where by the rate of production of the metabolite exceeds the availability of glutathione, hepatotoxiciy occurs. Liver necrosis can therefore

* Corresponding author occur when the level of glatathone is nearly depleted (Brodie, et al, 1973).

The liver contains numerous enzymes some of which are also present in serum in very low concentration. These enzymes have no known function in serum other than to provide information about hepatic state and disorders.Reports of Kaplowitz, 1992; Dede, 1992 indicated that elevated serum transferase and alkaline phosphatase levels as indicators of liver necrosis.

The aim of the current study therefore, is to study the biochemical changes that occurs in the serum (enzymelevels) and liver of albino rats exposed to petroleum samples (gasoline, kerosene and crude petroleum (bonny light).

\section{MATERIALS AND METHODS}

71 male albino rats of $0.2 \mathrm{~kg}$ body weight, obtained from Biochemistry and Pharmacology Departmental animal houses, University of Port - Harcourt Choba, Port Harcourt, Nigeria were used for the current study. The animals were acclimatized in the Pharmacology laboratory for six weeks. The animals were then divided in three groups (gasoline, kerosene and crud petroleum) and $5.0 \mathrm{gkg}^{-1}, 7.5 \mathrm{gkg}^{-1}$ and $15 \mathrm{gkg}^{-1}$ of the petroleum samples gasoline, kerosene and bonny light were administered in the rats respectively.

Each petroleum sample had twenty-seven rats for the three months study. Twelve rats served as 
control. The animals were fed adlibitum and given water freely. Twelve rats were sacrificed at the end of each month for the three months study. The levels of the parameters viz: Aspartate transaminase (AST). Alanine phosphatase (ALP), Glutathione transferase (GST) and Glutathione (GSH) were monitored.

ALP, ALT, and AST were determined from the cardiac bloodcollected with sanple bottles without anticoagulant. The blood was centifuged for $10 \mathrm{mins}$ at 300rpm and the resulting serum used for analysis. The activities of AST and ALT were determined from the cardiac blood collected with sample bottles without anti coagulant. The blood was centrifuged for 10mins at 300rpm and the resulting serum used for analysis. The activities of AST and ALT were determined using Rritman and Frankel 1957 method. ALP activity determined employing Bowers and McComb 1975 method. The livers of the animals sacrificed were collected for GSH and GST evaluation. GSH activity was determined using Anosike et al 1991 method and GSH Reeve et al, 1980.

\section{RESULTS}

Gasoline and kerosene substantially increased AST ALT and ALP enzyme levels consistently from $1^{\text {st }}$ month to the third month. This was significantly different from control $(\mathrm{p}<0.05)$ Table 1 . Crude petroleum also showed an increase consistently in marginally with gasoline treated rats. The GST level however increased marginally with gasoline treated rats. The GST in kerosene and crude petroleum (bonny light) treated rats increased significantly from $\mathrm{P}<0.05$. The GSH levels showed consistent reduction in levels from first to third month and was significantly different from control $\mathrm{P}<0.05$ (Table 1 ).

Table 1. Effect of $5.0 \mathrm{~g} / \mathrm{kg}$ gasoline, $7.5 \mathrm{~g} / \mathrm{kg}$ kerosine and $15.0 \mathrm{~g} / \mathrm{kg}$ crude petroleum - (Bonny Light) in Albino rats.

\begin{tabular}{|c|c|c|c|c|}
\hline Samples & Parameters & $\begin{array}{l}1^{\text {st }} \text { Month } \\
\text { U/L }\end{array}$ & Month & Month \\
\hline $\begin{array}{l}\text { Control } \\
\text { Gasoline }(5.0 \mathrm{~g} / \mathrm{kg}) \\
\text { Kerosine }(7.5 \mathrm{~g} / \mathrm{kg}) \\
\text { Crude Petroleum } \\
15.0 \mathrm{~g} / \mathrm{kg}\end{array}$ & $\begin{array}{l}\text { Asparate } \\
\text { Transaminase } \\
(\text { AST) } \mu / l\end{array}$ & $\begin{array}{l}44.8+3.3^{\mathrm{xx}} \\
27.0+2.0^{\mathrm{x}}\end{array}$ & $\begin{array}{l}47.00+4.0^{\mathrm{xx}} \\
30 .+2.0^{\mathrm{x}}\end{array}$ & $\begin{array}{l}20.00+2.0 \\
69.0+2.8^{\mathrm{xxx}} \\
58.0+3.0^{\mathrm{xx}} \\
33.0+0.5^{\mathrm{x}}\end{array}$ \\
\hline $\begin{array}{l}\text { Control } \\
\text { Gasoline }(5.0 \mathrm{~g} / \mathrm{kg}) \\
\text { Kerosine }(7.5 \mathrm{~g} / \mathrm{kg}) \\
\text { Crude Petroleum } \\
15.0 \mathrm{~g} / \mathrm{kg}\end{array}$ & $\begin{array}{l}\text { Alanine } \\
\text { Transaminase } \\
(\mathrm{ALT}) \mu / 1\end{array}$ & $\begin{array}{l}22.67+4.41^{\mathrm{xx}} \\
20.00+4.20^{\mathrm{x}}\end{array}$ & $\begin{array}{l}11.00+1.41 \\
59.58+1.54^{\mathrm{xxx}} \\
25.17+5.86^{\mathrm{xx}} \\
21.67+5.25^{\mathrm{x}}\end{array}$ & $\begin{array}{l}13.00+1.41 \\
62.00+12.83^{\mathrm{xxx}} \\
29.75+9.67^{\mathrm{xx}} \\
27.00+3.16^{\mathrm{x}}\end{array}$ \\
\hline $\begin{array}{l}\text { Control } \\
\text { Gasoline }(5.0 \mathrm{~g} / \mathrm{kg}) \\
\text { Kerosine }(7.5 \mathrm{~g} / \mathrm{kg}) \\
\text { Crude Petroleum } \\
15.0 \mathrm{~g} / \mathrm{kg}\end{array}$ & $\begin{array}{l}\text { Alkaline } \\
\text { Phosphate } \\
\text { (ALP) } \mu / l\end{array}$ & $\begin{array}{l}61.71+3.40 \\
147.71+9.8^{\mathrm{xxx}} \\
87.32+1.30^{\mathrm{xx}} \\
81.60+1.40^{\mathrm{x}}\end{array}$ & $\begin{array}{l}61.21+3.46 \\
160.59+21.90^{\mathrm{xxx}} \\
93.59+11.59^{\mathrm{xx}} \\
88.14+12.77^{\mathrm{x}}\end{array}$ & $\begin{array}{l}63.66+6.92 \\
161.00+45.00^{\mathrm{xxx}} \\
123.64+30.05^{\mathrm{xx}} \\
90.50+6.32^{\mathrm{x}}\end{array}$ \\
\hline $\begin{array}{l}\text { Control } \\
\text { Gasoline }(5.0 \mathrm{~g} / \mathrm{kg}) \\
\text { Kerosine }(7.5 \mathrm{~g} / \mathrm{kg}) \\
\text { Crude Petroleum } \\
15.0 \mathrm{~g} / \mathrm{kg}\end{array}$ & $\begin{array}{l}\text { Glutathione-s } \\
\text { Transferase } \\
(\text { GST) } \mu / l\end{array}$ & $\begin{array}{l}13.00+1.40 \\
18.50+1.06^{\mathrm{x}} \\
27.67+3.01^{\mathrm{xxx}} \\
22.67+2.16^{\mathrm{xx}}\end{array}$ & $\begin{array}{l}12.50+0.71 \\
18.25+1.54^{\mathrm{x}} \\
28.17+5.86^{\mathrm{xxx}} \\
23.83+2.80^{\mathrm{xx}}\end{array}$ & $\begin{array}{l}14.50+0.71 \\
17.00+1.41^{\mathrm{x}} \\
29.00+4.08^{\mathrm{xxx}} \\
25.25+2.22^{\mathrm{xx}}\end{array}$ \\
\hline $\begin{array}{l}\text { Control } \\
\text { Gasoline }(5.0 \mathrm{~g} / \mathrm{kg}) \\
\text { Kerosine }(7.5 \mathrm{~g} / \mathrm{kg}) \\
\text { Crude Petroleum } \\
15.0 \mathrm{~g} / \mathrm{kg}\end{array}$ & $\begin{array}{l}\text { Glutathione } \\
\mathrm{mm} / \mathrm{gm} \\
(\mathrm{GSH})\end{array}$ & $\begin{array}{l}0.56+0.07 \\
0.28+0.1^{\mathrm{xxx}} \\
0.38+0.06^{\mathrm{x}} \\
0.40+0.06^{\mathrm{xx}}\end{array}$ & $\begin{array}{l}0.61+0.10 \\
0.44=0.19^{\mathrm{xxx}} \\
0.72+0.8^{\mathrm{x}} \\
0.47+0.1^{\mathrm{xx}}\end{array}$ & $\begin{array}{l}0.67+0.45 \\
0.43+0.01^{\mathrm{xxx}} \\
0.30+0.10^{\mathrm{x}} \\
0.41+0.62^{\mathrm{xx}}\end{array}$ \\
\hline
\end{tabular}

\section{DISCUSSION}

Serum activities of AST $<$ ALT $<$ and ALP showed a significant elevation from the first month of exposure till the end of three months study. GST equally showed a significant rise from the first to the third month. However, GSH showed a significant decrease after the first dose, mildly elevated after second dose and markedly depleted after the third dose.

Elevation of ALT activity appears to reflect hepatic disease and it is more specific for hepatic disease than AST because of the biological location of the enzymes. Though the activity of either enzyme particularly AST may be elevated also in extra 
hepatic disease. However the elevation of AST and ALT along with the elevation of ALP activity may reflect some inflammatory disease or injury to the liver. In the present work, the maximum activity of ALP obtained for gasoline and kerosene for the third month was more than two fold, so there is the possibility of hepatocellular damage. Some workers have illustrated that enzyme pattern in the serum reflects the physiological state of the organ. For instance increase in serum levels of AST, ALT and ALP was observed in serum of fish exposed to 2,3,4 -triaminoazo benzene resulting to the hepatocellular damage (Krishan and Veena 1980). Other studies also indicated increase in the activities of the liver enzyme following liver damage in fish and albino mouse exposed to toxic substances (Dheer et al 1987, Mohssen Morowati 1997 and Sharpe et al 1996). The result of this study is in uniform to these findings.

Inactivation of GST by gasoline may be responsible for the low activity of GST in rats injected gasoline.Chiapotto et al 1995 reported inactivation of GST by different concentrations of acetaldehyde and the result of this study on GST activity on rats injected gasoline seems similar.

The longer detoxification process resulting from the varying chemical composition of kerosene and crude oil (bonny light) together with increase biochemical changes that usually accompanied such process may account for the increase in activity of GST in the rats administered kerosene and crude oil (bonny light) as observed in this study. Some studies have indicated not only the importance of GST in detoxification of metabolites but also in regulation of stress (Anosike et al 1991, Rajendra et al 1996 and Sharpe et al 1996). It is clear that the result obtained in current study is in agreement with such findings of these authors.

The marked reduction in level of GSH mainly observed in the first and third months may not necessarily be as a result of its utilization in the conjugation of reactive metabolites generated from these petroleum samples as observed in the study of Jollow et al (1973), Brodie et al (1973), Guerri and Grisolia (1980), Reeve et al (1980) and Sharpe et al (1996), but rather due to decreasein synthesis of GSH caused by functional disturbance brought about by inflammation of the liver. Incidentally the liver is the primary site for the synthesis of many substances including plasma proteins and short peptide example glutathion. Therefore under severe or long-standing hepatic disease there will be decrease synthesis of some substances.

From the above, it may be concluded that such biochemicalchanges as observed in the experimental animals may be seen in human beings. It is important that one avoid any exposure to thesesamples and therapeutic use of these petroleum samples should highly be discouraged.
Acknowledgement: The authors acknowledge with thanks the assistance of Mr. A. T. Agbaje in producing some of the reagents used in this study from London, also the workers in Chemical Pathology Laboratory of University of Port Harcourt Teaching Hospital and Abia University State Teaching Hospital, Aba.

\section{REFERENCES}

Afolabi, O. A., Adeyemi, S. A. ; Imevboro, M.A. (1985). Studies of toxicity of some Nigeria Crude oil to some Aquatic Organism Chem. Inst. of Ecology, University of Ife Nigeria 269-290.

Anderson, J. N., Neff, J. M. , Acox, B., Tatem, H. E. ; Hightower, G. M. (1974). Characteristics of dispersion and water soluble extracts of crude and refined oils and their toxicity to eutuarine crustaceans and fish Mar Bio 27 75-88.

Anosike, O. E. Uwakwe, A.A., Monano, O. M. ; Ekeke, I. G. (1991). Studies on human erythrocytes glutathione-s- transferase from $\mathrm{Hb} \mathrm{AA} \mathrm{Hb}$ AS and $\mathrm{Hb}$ SS subjects Biochim, Acts 50 1051-1056.

Bowers , G. N. ; McComb, R. B. (1975). Measurement of total alkaline phosphatase activity in human serum clinical chemistry 1988-1995.

Brodie, B. B. Jollow, D. J. Potter, W. Z., Gillette, J. R. ; Mitchel, J. R. (1973). Acetaminophen induced Hepatic Necrosis 1V Protective role of Glutathione, U.S.A. Journal of pharmacology and experimental therapeutics 187, $211-216$.

Chiapotto e, Biasi, f, Scavazza, A, Camandola, S. Aragno, M Tamagno, E. O. Dianzan, M. U., Poli, G. (1995).

Acetaldehyde involvement in ethanol induced potentiation of rats hepatocyte damage due to the carcinogen 1,2 - dibromoethanol. Alcohol - alcohol. 1995 Nov., 30 (6): 72, 18.

Dheer J. M., Dheer T. R. ; Mahajan C. L. (1987). Haematological and haematopietic response to acid stressin an air breathing fresh water fish channal punctatus. Bioch. J. Fish Bio 30, 577-588.

Ezeala, D. U. (1987). The sensitivity of pistia stratoites (A fresh water plant) to crude oil pollution. Teopic Agric 28, 194-6 
Guerri, C. ; Grisolia, S. (1980). Changes in glutathione in acute and chronic alcohol intoxication, U. S. A. Journal of pharmacology Biochemistry 13, 53-61.

Jollow, D. G., Mitchell J. R., Potter, W. Z., Davis , D. C. , Gillette J. R. , Brodie, B. B. (1973). Acetaminopen - induced hepatic necrosis 11 . Role of covalent binding invivo U. S. A. Journal of pharmacology and Experimental Therapeutics 187, $195-202$.

Kiceniuk, J. W., Khan, R. A., Dawe, M. ; Williams U. (1982). Examination and interaction of trypanosome infection and crude oil exposure on haematology of the Longhorn Sculphin (Myoxocephalus octodeces pinosus). Bull Environm, Contam- Toxi. Col. 28 435-438.

Krishan, A. G. and Veena, G. (1980). 2,3,4Triaminoazo benzene- induced hemato biochemical Anomalies in fish (Channa puntatus) Bull Environm.Contam. Toxicol 25 $136-141$.

Kuhnhold, W.W., Everish, D. Stegeman, J. J., Lake, J. ; Woike, R. E. (1980). Effects of low-level hydrocarbon on embryonic, Larval and adult winter flounder (pseudopleurnertes americanus). Impact of oil spills 14-17 June _ 1978, Keystone, Colorado USA America Institute of Biological Science, Washington DC 678-80.

Mohssen Morowati (1997). Inhalation toxicity studies of thimet (phorate) in male swiss albino mouse, MUS Musculus: Environment Pollution Vol. 96 No. 3 383-388.

Onuoha , C. G., ; Nwadukwe, F. O. (1990)

Influence of liquid petroleum Refinery effluent on the hatching success of carias gariepinus (african mud fish) eggs. Environment and Ecology 8 (4) 1201 - 1206.

Owell, B. C. (1987). Effects of fresh oil spillages on fish and fisheries, Environmental impact assessment, Report Number 30 208- 236.

Rajendra, S. Parasakthy, K., Deepalakshmi, P. D., Devaraji S. N. (1996). Oxidative stress in rat liver and lung induced by Furanoterpenolds Isolated from Fusariumsolan infected sweet potatoes.

Reitman, S. and Frankel, S. (1957). Colormetic assay of Alanine and Aspartate aminotransferase Amer J. Clin. Path 28, 56.

Reev, J., Goldstein L., Kuhlenkamp, J. ; Kaplowitz, $\mathrm{N}$ (1980). Effect of salicylates and phenobarbiturate on hepatic glutathionein rats U. S. A. Journal of pharmacology and Experimental Therapeutics 212 240-245.

Sharpe P. C., McBride, R ;Archbold G. P. (1996). Biochemical markers of alcohol abuse medicine 89 (2) 137-44.

Udo, E. J. ; Fayemi, A. A. (1975). The effect of oil pollution on soil germination and nutrient uptake of corn. J. Environ Quart 4 537-540. 